7. Про основні засади соціального захисту ветеранів праці та інших громадян похилого віку в Україні: Закон України від 16.12.1993 № 3721-XII. Відомості Верховної Ради України. 1994 р. № 4. Стаття 18.

8. Новосельська I., Руше М. Кодифікація законодавства України із соціального забезпечення. Підприємництво, господарство і право. 2017. № 7. С. 43-45.

9. Кучма О.Л. Перспективи систематизації законодавства в сфері соціального страхування. Університетські наукові записки. 2016. № 3. С. 218-224.

10. Європейський кодекс соціального забезпечення (переглянутий): Міжнародний документ від 06.11.1990 № ETS N 139. URL: https://zakon.rada.gov.ua/laws/show/994_651 (дата звернення 06.09.2019 року).

11. Соціальний кодекс України: Проект Закону України №2311 від 15.02.2013. URL: http://w1.c1.rada.gov.ua/pls/zweb2/webproc4_2?pf3516=2311\&skl=8 (дата звернення 06.09.2019 року).

12. Про загальнообов'язкове державне соціальне страхування: Закон України від 23.09.1999 № 1105-XIV. Відомості Верховної Ради України. 1999. № 46-47. ст.403.

13. Про державну соціальну допомогу малозабезпеченим сім'ям: Закон України від 01.06.2000 № 1768-III. Відомості Верховної Ради України. 2000 р. № 35. стаття 290.

14. Про державну соціальну допомогу особам з інвалідністю $з$ дитинства та дітям з інвалідністю: Закон України від 16.11.2000 № 2109-ІІІ. Відомості Верховної Ради України. 2001 р. № 1. Стаття 2 .

15. Про державну соціальну допомогу особам, які не мають права на пенсію, та особам 3 інвалідністю: Закон України від 18.05.2004 № 1727-IV. Відомості Верховної Ради України. 2004 p. № 33-34. Стор. 1354. Стаття 404.

16. Свропейська соціальна хартія (переглянута): Міжнародний документ від 03.05.1996. Відомості Верховної Ради України. 2007 р. № 51. стор. 2096.

17. Про ратифікацію Європейської соціальної хартії (переглянутої): Закон України від 14.09.2006 № 137-V. Відомості Верховної Ради України. 2006. № 43. Ст. 418.

18. Sozialgesetzbuch (SGB). URL: https://www.gesetze-im-internet.de/sgb_11/SGB_11.pdf (дата звернення 06.09.2019 року).

УДК 349.2

DOI https://doi.org/10.32844/2618-1258.2019.6.12

КИРИЗЛІЕВ О.Ф.

\title{
СПЕЦИФІКА ВИНИКНЕННЯ ПРАВОВІДНОСИН ІЗ ПРАЦІВНИКАМИ ФІНАНСОВИХ УСТАНОВ
}

У статті визначено, що юридичний факт як підстава виникнення, зміни та припинення трудових правовідносин з працівниками фінансових установ - це конкретна життєва обставина у формі дії (наприклад, укладення чи розірвання трудового договору), чи події (для прикладу, завершення строку дії строкового трудового договору), яка має конкретний зміст та зовнішній вираз, прямо чи опосередковано передбачена нормами права у встановленій законодавством процесуальній формі (зокрема, Кодексу законів про працю України, Положення про навчання, перепідготовку, підвищення кваліфікації та складання екзаменів особами, які провадять діяльність на ринках фінансових послуг від 25.12.2003 № 183 та ряду інших нормативно-правових актів), і з якими норми права пов'язують настання правових наслідків у вигляді виникнення, зміни та припинення трудових правовідносин з працівниками фінансових установ. 3'ясовано, що норма права як умова виникнення трудових правовідносин з працівниками фінансових установ включає таке: по-пер-

( С КИРИЗЛІЄВ О.Ф. - голова (Чабанівська селищна рада) 
ше, закріплення загальних умов виникнення трудових правовідносин 3 працівниками фінансових установ, серед яких насамперед варто виділити унормування процесу укладення трудового договору; по-друге, юридичні факти, які зумовлюють виникнення будь-яких інших (суміжних) відносин між роботодавцями та працівниками фінансових установ і також знаходять своє закріплення у нормах чинного законодавства. Зроблено висновок, що до специфічних рис виникнення трудових правовідносин з працівниками фінансових установ слід віднести таке: 1) для виникнення трудових правовідносин з працівниками фінансових установ особа, яка претендує на заняття вакантної посади в таких установах, має бути правосуб'єктною, тобто відповідати вимогам щодо віку, стану здоров'я, досвіду та рівня професійної компетенції; 2) для виникнення трудових правовідносин з працівниками фінансових установ необхідна наявність правових норм, які урегульовують цей процес; 3) для виникнення трудових правовідносин з працівниками фінансових установ необхідна наявність юридичних фактів, закріплених у правових нормах, серед яких нами відзначено передусім укладення трудового договору.

Ключові слова: трудові правовідносини, фінансова установа, правосуб'єктність, тимчасова адміністрація.

The article defines that a legal fact, as the basis for the emergence, change and termination of employment relations with employees of financial institutions, is a specific life circumstance in the form of an action (eg, the conclusion or termination of an employment contract), or an event (for example, the expiration of the term employment contract), which has a specific meaning and external expression, directly or indirectly provided by the rules of law in the procedural form established by law (in particular, the Labor Code of Ukraine, the Regulations on training, retraining training, qualification and examination by persons conducting activities in the markets of financial services No. 183 and other legal acts dated 25.12.2003), and with which the norms of law are associated with the occurrence of legal consequences in the form of occurrence, change and termination of employment legal relations with employees of financial institutions. It is found that the rule of law, as a condition for the emergence of employment relations with employees of financial institutions, includes the following: first, the fixing of the general conditions for the emergence of employment relations with employees of financial institutions, among which is first of all to highlight the normalization of the process of concluding an employment contract; secondly, the legal facts that give rise to any other (related) relationship between employers and employees of financial institutions also find their place in the rules of current law. It is concluded that the specifics of the emergence of employment relationships with employees of financial institutions are the following: 1) for the emergence of employment relationships with employees of financial institutions, the person applying for a vacant position in such institutions must be legal person, is meet the age requirements, health status, experience and level of professional competence; 2) the existence of legal relations with employees of financial institutions requires the existence of legal rules governing this process; 3 ) the existence of legal relations with employees of financial institutions requires the presence of legal facts, enshrined in legal norms, among which we noted above all the conclusion of an employment contract.

Key words: labor relations, financial institution, legal personality, temporary administration.

Вступ. Будь-які суспільні відносини, врегульовані нормами права, починаючи із моменту свого виникнення, постійно перебувають у динаміці, яка реалізується у їх постійному розвитку, який продовжується аж до моменту припинення. Виникнення, розвиток та припинення будь-яких правових відносин пов'язується із певними особливими, притаманними лише ним підставами та умовами. Не $\epsilon$ винятком у контексті і правовідносини з працівниками фінансових установ, адже для виникнення, розвитку та припинення правовідносин з працівниками фінансових установ також необхідна наявність певних достатніх підстав та умов, які застосовуються у необхідній кількості та у визначеному порядку. Як свідчать праці вітчизняних науковців, безсумнівним $є$ те, що 
такі підстави та умови не варто обмежувати винятково наявністю відповідних норм вітчизняного законодавства (норм Кодексу законів про працю України [1], Законів України «Про фінансові послуги та державне регулювання ринків фінансових послуг» від 12.07.2001 № 2664-III [2], «Про банки та банківську діяльність» від 07.12.2000 № 2121-ІІІ [3] чи інших нормативно-правових актів), адже норми цих нормативно-правових актів не породжують, змінюють чи припиняють правовідносин $з$ працівниками фінансових установ, а визначають правила та критерії можливості чи допустимості певної поведінки у суспільстві, зумовлюють варіанти можливої поведінки і забезпечують їх охорону у межах правових відносин. Проте для того, щоб виникнення, зміна та припинення правовідносин з працівниками фінансових установ все ж відбулось, необхідні юридичні підстави для цього, а також зацікавленість суб'єктів правовідносин (або одного із них).

У юридичній літературі та на практиці, виникнення, зміна чи припинення будь-яких правовідносин передусім зумовлюється наявністю певних життєвих фактів, здійснення яких знайшло регламентацію у нормативно-правових актах, з якими законодавець пов'язує можливість здійснення учасниками правовідносин їх суб'єктивних прав і юридичних обов'язків та які дістали назву юридичних фактів. Юридичні факти оточують кожного із нас у повсякденному житті, й ними супроводжуються усі правові дії, що вчиняються сторонами будь-яких правовідносин. Відповідно, юридичні факти, безумовно, є значимими і для функціонування фінансових установ, адже вони у тому числі в обов'язковому порядку породжують юридичні наслідки трудової взаємодії із працівниками фінансових установ. Юридичний факт є обов'язковою умовою виникнення, припинення та розвитку правовідносин з працівниками фінансових установ, адже кожен юридичний факт упорядковує соціальні зв'язки між сторонами таких правовідносин, визначає юридичну чинність їхніх прав і обов'язків, а також наслідок їхнього дотримання. Держава своєю чергою, закріплюючи їх у гіпотезах норм права, визначає ті життєві умови, обставини і факти, які $є$ значимими для виникнення, розвитку та припинення правовідносин з працівниками фінансових установ, та встановлює правила поведінки суб'єктів правовідносин з такими працівниками. Все вищезазначене зумовлює важливість дослідження виникнення, розвитку та припинення правовідносин з працівниками фінансових установ як складника змісту правового статусу працівників фінансових установ.

Стан дослідження. У юридичній літературі загальнотеоретичні питання виникнення, розвитку та припинення правовідносин традиційно розглядаються великою кількістю дослідників. Проте варто враховувати, що питання виникнення, зміни та припинення правовідносин 3 працівниками фінансових установ є новим для вітчизняної науки. Серед дослідників, які фрагментарно звертали увагу на питання, близькі до досліджуваного, відзначимо внесок таких, як В.Б. Авер'янов, М.М. Агарков, О.Ф. Андрійко, А.Б. Альтшуллер, Ю.П. Битяк, І.А. Безклубий, А.А. Вишневський, Л.К. Воронова, Н.В. Воротіна, В.П. Грибанова, О.М. Гладчук, О.Л. Дорош, О.А. Дмитрієва, Н.В. Дроздова, А.М. Екмалян, А.І. Камінка, А.Т. Ковальчук, Н.М. Квіт, В.Ф. Колісніченко, О.М. Колодзієва, В.В. Корєєва, С.М. Лепех, В.П. Нагребельний та інших. Проте стан дослідження питання особливостей виникнення, розвитку та припинення правовідносин з працівниками фінансових установ $є$ вкрай низьким, що зумовлює актуальність здійснення такого дослідження.

Постановка завдання. Метою статті є дослідження специфіки виникнення правовідносин із працівниками фінансових установ.

Результати дослідження. Як нами встановлено, відповідно до пункту 1 статті 1 Закону України «Про фінансові послуги та державне регулювання ринків фінансових послуг» від 12.07.2001 № 2664-III [2], до фінансових установ належать банки, кредитні спілки, ломбарди, лізингові компанії, довірчі товариства, страхові компанії, установи накопичувального пенсійного забезпечення, інвестиційні фонди і компанії та інші юридичні особи, винятковим видом діяльності яких є надання фінансових послуг, а у випадках, прямо визначених законом, інші послуги (операціï), пов'язані з наданням фінансових послуг, аналіз виникнення, зміни та припинення правовідносин з працівниками фінансових установ, варто розглядати у контексті трудових правовідносин із працівниками цих органів. Тобто особи, які бажають реалізувати своє конституційне право на працю у цій сфері, можуть бути працевлаштовані у одному із вищенаведених органів, i саме у цьому контексті варто розглядати динаміку розвитку досліджуваних правовідносин.

У науковій літературі загальноприйнятою $є$ концепція, згідно з якою виникнення, розвиток та припинення правовідносин здійснюється на підставі юридичних фактів. Такий підхід, наприклад, знаходить своє підтвердження у працях М.В. Цвіка та О.В. Петришина [4, с. 346], С.Д. Гусарєва та О.Д. Тихомирова [5, с. 208], К.Г. Волинки [6, с. 160], О.В. Зайчука та Н.М. Оніщенко [7, с. 447] та у працях багатьох інших теоретиків права. Тобто це питання не є дискусійним 
та не піддається сумнівам, а отже, юридичні факти є підставою і для виникнення, розвитку та припинення правовідносин з працівниками фінансових установ. Таким чином, для встановлення сутності юридичного факту як підстави для виникнення, розвитку та припинення правовідносин з працівниками фінансових установ розглянемо значення одного із таких підходів.

Так, у підручнику «Загальна теорія держави і права» за редакцією М.В. Цвіка та О.В. Петришина юридичні факти тлумачаться як конкретні життєві обставини (дії та події), з якими норми права пов'язують настання певних правових наслідків - виникнення, зміну або припинення правових відносин [4, с. 346]. Отже, юридичні факти, які здійснюють вплив на виникнення, зміну або припинення правовідносин 3 працівниками фінансових установ, варто розглядати у таких аспектах: по-перше, вони являють собою дії чи події (діями є сукупність вчинків [8, с. 306], тобто те, що залежить від волі людини, а подією - певне явище чи факт суспільного життя [8, с. 1009], тобто те, що не залежить від волі людини); по-друге, норми права пов'язують настання правових наслідків із дією юридичних фактів (наприклад, у частині 2 статті 21 Кодексу законів про працю України [1] передбачено, що «працівник має право реалізувати свої здібності до продуктивної і творчої праці шляхом укладення трудового договору на одному або одночасно на декількох підприємствах, в установах, організаціях, якщо інше не передбачене законодавством, колективним договором або угодою сторін» - у цьому контексті юридичним фактом є укладення трудового договору, яке створює правові наслідки у формі виникнення трудових правовідносин та створює передумови для реалізації працівником фінансової установи своїх здібностей до продуктивної і творчої праці у цій сфері); по-третє, у цій дефініції прямо вказано на те, що юридичні факти є підставою виникнення, розвитку та припинення трудових правовідносин із працівниками фінансових установ.

А отже, виникнення, розвиток та припинення трудових правовідносин з працівниками фінансових установ здійснюється на підставі юридичних фактів, вплив яких розкривається у таких аспектах:

- по-перше, юридичними фактами, на підставі яких виникають, розвиваються чи припиняються трудові правовідносини із працівниками фінансових установ, можуть бути як дії, так і події.

- У цьому аспекті прикладом дії є укладення чи розірвання трудового договору із такими особами. Укладення та розірвання є діями із огляду на те, що вони залежать від волі сторін укладення договору, їх можна окреслити як вчинки. Своєю чергою подією, яка має вплив на виникнення, розвиток та припинення трудових правовідносин з працівниками фінансових установ, може бути смерть працівника чи завершення строку дії строкового трудового договору. У такому разі настання цих обставин виникає об'єктивно та не залежить безпосередньо від вчинків сторін трудового договору.

- по-друге, правові наслідки дії юридичних фактів передбачено у нормах законодавства, яке урегульовує трудові правовідносини із такими працівниками фінансових установ.

До таких нормативно-правових актів, наприклад, можна віднести Кодекс законів про працю України [1], Положення про навчання, перепідготовку, підвищення кваліфікації та складання екзаменів особами, які провадять діяльність на ринках фінансових послуг від 25.12.2003 № 183 [9], та ряд інших нормативно-правових актів. Тобто аналіз окремих норм цих нормативно-правових актів засвідчить закріплення у їхньому змісті правових наслідків дії юридичних фактів, які породжують виникнення, зміну чи припинення трудових правовідносин з працівниками фінансових установ. Приклад такої норми Кодексу законів про працю України [1] вже нами наводився раніше. Щодо інших прикладів, то можна розглянути будь-яку із підстав розірвання трудового договору. Наприклад, пунктом 1 частини 1 статті 40 цього нормативно-правового акту передбачено, що трудовий договір, укладений на невизначений строк, а також строковий трудовий договір до закінчення строку його чинності, можуть бути розірвані власником або уповноваженим ним органом у разі змін в організації виробництва і праці, в тому числі ліквідації, реорганізації, банкрутства або перепрофілювання підприємства, установи, організації, скорочення чисельності або штату працівників. У такому разі зміни в організації виробництва і праці і є юридичними фактами, які закріплені у нормах законодавства і породжують правові наслідки у вигляді припинення трудових правовідносин із працівниками фінансових установ. Таким самим чином відбувається закріплення наслідків впливу юридичних фактів і у інших нормативно-правових актах, які врегульовують трудові правовідносини із працівниками фінансових установ.

Отже, зробимо висновок, що виникнення, зміна та припинення правовідносин 3 працівниками фінансових установ здійснюються на основі конкретних життєвих обставин, а саме дій чи подій, які здійснюють безпосередній вплив на їх розвиток. Такі юридичні факти мають чітко 
визначений зміст, є зовнішньо вираженими, фіксуються у нормах законодавства та породжують юридичні наслідки, якими, власне, і $є$ виникнення, зміна та припинення правовідносин з працівниками фінансових установ.

Також у підручнику «Загальна теорія держави і права» за редакцією М.В. Цвіка та О.В. Петришина авторами було визначено ознаки юридичних фактів, які ми пропонуємо проаналізувати через призму юридичних фактів, які здійснюють вплив на виникнення, зміну та припинення трудових правовідносин з працівниками фінансових установ [4, с. 346]. Серед ознак дослідниками виділено такі:

1) Юридичними фактами є життєві обставини, які полягають у наявності або відсутності певних явищ матеріального світу.

Прикладом юридичного факту, який полягає у наявності певних явищ матеріального світу, $\epsilon$ укладення трудового договору. Як нами вже відзначалось раніше, укладення трудового договору $є$ юридичним фактом, який спричиняє юридичний наслідок у вигляді виникнення трудових правовідносин з працівниками фінансових установ. Для наведення прикладу юридичного факту, який полягає у відсутності певних явищ матеріального світу, звернемось до Положення про навчання, перепідготовку, підвищення кваліфікації та складання екзаменів особами, які провадять діяльність на ринках фінансових послуг від 25.12.2003 № 183 [9]. Зокрема, у його пункті 1.5. визначено, що «підвищення кваліфікації осіб, які мають намір отримати сертифікат Нацкомфінпослуг на право здійснення тимчасової адміністрації фінансової установи, здійснюється згідно 3 цим Положенням відповідно до затвердженої Нацкомфінпослуг типової програми підвищення кваліфікації осіб, які мають намір отримати сертифікат Нацкомфінпослуг на право здійснення тимчасової адміністрації фінансової установи». Це означає, що відсутність такого сертифікату Нацкомфінпослуг є юридичним фактом, який зумовлює виникнення правовідносин підвищення кваліфікації працівника фінансових установи, що своєю чергою доречно розглядати як підставу зміни правовідносин з працівниками фінансових установ.

2) Для них характерний конкретний зміст та зовнішній вираз, тобто юридичні факти існують у певному місці і часі і містять інформацію про стан суспільних відносин, що входять до предмета правового регулювання.

Так, ведучи мову про укладання чи розірвання трудового договору з працівниками фінансових установ, ми говоримо про конкретні, а не абстрактні юридичні факти. Правовідносини 3 працівниками фінансових установ виникають, змінюються чи припиняються внаслідок дії конкретних фактів: укладення чи припинення трудового договору, навчання, перепідготовка чи підвищення кваліфікації тощо. Це певна чітко визначена у місці і часі дія чи подія, яка реально реалізовується та породжує правові наслідки.

3) Юридичні факти характеризуються прямим або опосередкованим передбаченням нормами права та фіксуються у встановленій законодавством процесуальній формі.

Як нами відзначалось, юридичні факти безпосередньо визначаються у нормах нормативно-правових актів, які урегульовують трудові правовідносини із працівниками фінансових установ. Якщо проаналізувати більшість норм Кодексу законів про працю України [1], можна звернути увагу на те, що визначене у нормі положення та очікувані юридичні наслідки можна співвіднести як умову та результат іії виконання. Наприклад, статтею 40 цього нормативно-правового акту передбачено перелік випадків, за яких може бути розірвано трудовий договір 3 ініціативи власника або уповноваженого ним органу. Наприклад, трудовий договір може бути розірвано у разі змін в організації виробництва і праці, в тому числі ліквідації, реорганізації, банкрутства або перепрофілювання підприємства, установи, організації, скорочення чисельності або штату працівників. Тобто, якщо розглядати зміни в організації виробництва і праці як юридичний факт, передбачений нормою Кодексу законів про працю України [1], то результатом його реалізації є припинення правовідносин з працівниками фінансових установ. Тобто юридичні факти, які спричиняють виникнення, зміну чи припинення правовідносин, дійсно фіксуються у нормах права.

4) Юридичні факти створюють юридичні наслідки, передбачені нормами права.

Як нами вже неодноразово наголошувалось, юридичні факти у сфері трудових правовідносин створюють юридичні наслідки у формі виникнення, зміни чи припинення правовідносин 3 працівниками фінансових установ.

Звертаючись до наукової літератури галузі трудового права, зробимо висновок, що сутність юридичних фактів розуміється таким самим чином. Наприклад, Л.В. Солодовник визначила юридичні факти у трудовому праві України як конкретні обставини реальної дійсності, 
3 якими норми права пов'язують виникнення настання юридичних наслідків, тобто виникнення, зміну, припинення трудових та суміжних з ними правовідносин, встановлення інших правових наслідків [10, с. 11]. Трудоправовий характер цієї дефініції проявляється лише у одному моменті - дослідницею наголошується, що юридичні факти здійснюють вплив не лише на виникнення, зміни чи припинення трудових, але й суміжних з ними правовідносин. Однак зміст цієї дефініції, по суті, $є$ тотожним з загальнотеоретичними концепціями.

Таким чином, із усього вищенаведеного слідує висновок, що юридичний факт як підстава виникнення, зміни та припинення трудових правовідносин з працівниками фінансових установ - це конкретна життєва обставина у формі дії (наприклад, укладення чи розірвання трудового договору), чи події (для прикладу, завершення строку дії строкового трудового договору), яка має конкретний зміст та зовнішній вираз, прямо чи опосередковано передбачена нормами права у встановленій законодавством процесуальній формі (зокрема, Кодексу законів про працю України [1], Положення про навчання, перепідготовку, підвищення кваліфікації та складання екзаменів особами, які провадять діяльність на ринках фінансових послуг від 25.12.2003 № 183 [9], та ряду інших нормативно-правових актів), і з якими норми права пов'язують настання правових наслідків у вигляді виникнення, зміни та припинення трудових правовідносин з працівниками фінансових установ.

Аналізуючи виникнення, зміну та припинення трудових правовідносин з працівниками фінансових установ, варто звернути увагу на те, що в науковій літературі галузі трудового права вчені розглядають будь-які трудові правовідносини, як такі, що виникають з моменту, коли працівник уклав 3 власником підприємства чи уповноваженим ним органом трудовий договір, контракт і приступив до виконання своєї трудової функції, або був фактично допущений власником до виконання робіт [11, с. 123]. Тобто виникнення правовідносин з працівниками фінансових установ варто пов'язати із укладенням працівником трудового договору із юридичною особою, винятковим видом діяльності якої є надання фінансових послуг, а у випадках, прямо визначених законом, - інших послуг (операцій), пов'язаних з наданням фінансових послуг. Відповідно, у трудовому праві загальноприйнятим $є$ такі форми припинення трудових відносин, як за волевиявленням їх суб'єктів, з ініціативи третіх осіб, у зв'язку із закінченням строку трудового договору або внаслідок смерті працівника [12, с. 123]. Своєю чергу змінюються будь-які трудові правовідносини у їх динаміці. Так, Я.В. Сімутіна вказує на те, що з моменту свого виникнення i за час існування трудові правовідносини зазнають постійних змін внаслідок появи нових і нових юридичних фактів, зазвичай актів реалізації прав і обов'язків суб'єктів [12, с. 111]. Отже, розглядаючи юридичні факти укладення та припинення трудового договору як підстави виникнення, зміни та припинення правовідносин з працівниками фінансових установ, зробимо висновок, що дія юридичних фактів також є підставою для їх зміни. При цьому варто враховувати, що юридичні факти, які настають в процесі розвитку трудових правовідносин, можуть бути негативними, позитивними та нейтральними. Щодо цього Я.В. Сімутіна відзначає, що позитивними фактами для розвитку трудових правовідносин $є$ підвищення кваліфікації чи виплата працівнику премії тощо. До негативних юридичних фактів віднесено порушення трудової дисципліни, завдання матеріальної шкоди. Серед нейтральних юридичних фактів виділено відрядження, тимчасове переведення на іншу посаду для заміни відсутнього працівника [12, с. 111]. У цьому контексті варто підкреслити, що зазначений перелік юридичних фактів є орієнтовним, але не вичерпним. Також необхідно враховувати, що специфіка фінансових установ значно розширює перелік юридичних фактів, які можуть впливати на виникнення, зміну та припинення правовідносин з працівниками фінансових установ.

Досліджуючи виникнення правовідносин з працівниками фінансових установ, варто враховувати, що воно передбачає обов'язкове дотримання наступних умов: правосуб'єктність (правоздатність і дієздатність), тобто сукупність трудової правоздатності та дієздатності; наявність правової норми, тобто існує відповідна правова норма, з моменту застосування якої правовідносини виникають та стають правовими; та, власне, наявність юридичного факту, з яким чинне законодавство пов'язує виникнення правових наслідків і який є підставою виникнення правовідносин [11, с. 124]. Тому пропонуємо розглянути, яким чином відбувається виникнення правовідносин з працівниками фінансових установ через призму специфіки кожної із умов.

Так, питання правосуб'єктності працівників фінансових установ, на нашу думку, варто розглядати у двох аспектах: як загальну правосуб'єктність працівників фінансових установ, умови якої визначаються Кодексом законів про працю України [1] та які є характерними для будь-якої сфери; як спеціальну правосуб'єктність. 
Загальна правосуб'єктність означає, що за наявності певних умов особа може бути суб'єктом конкретних правовідносин у сфері праці, володіти правами та обов'язками у цих правовідносинах або набувати їх своїми діями. Зокрема, варто вказати на те, що за загальним правилом, не враховуючи винятки, трудова правосуб'єктність (тобто правоздатність і дієздатність) працівників виникає з віку 16 років. Також в окремих випадках законодавство про працю може встановлювати граничний вік для виконання деяких видів роботи, проте за загальним правилом такий вік чинним законодавством не встановлено. Окрім того, категорія загальної трудової правосуб'єктності працівників фінансових установ може також враховувати стан здоров'я. Стосовно цього у статті 9 Закону України «Основи законодавства України про охорону здоров'я» від 19.11.1992 № 2801-XII [13] передбачена можливість обмеження прав громадян, пов’язана із станом їх здоров'я. Також чинним законодавством про працю визначено особливості трудової правосуб'єктності осіб із інвалідністю. Отже, загальна трудова правосуб'єктність передбачає можливість працевлаштування у фінансових установах осіб, які досягли віку 16 років та яким стан здоров'я дозволяє зайняти відповідну посаду. Але у той самий час до працівників фінансових установ висунуто ряд інших вимог, пов'язаних із їхньою професійною компетентністю, які і становлять їх спеціальну правосуб'єктність.

Спеціальна правосуб'єктність працівників фінансових установ вже розглядалась нами у цій роботі, і нами відзначалось, що основу трудової правосуб'єктності працівників фінансових установ складає здатність до праці, що зумовлюється фізичними й розумовими здібностями, а також підвищеними професійними якостями. Так, деякі категорії службовців фінансових установ, такі як працівник, відповідальний за проведення фінансового моніторингу, керівники та головні бухгалтери фінансових установ, окрім іншого, повинні володіти бездоганною діловою репутацією та відповідати іншим кваліфікаційним вимогам, встановленим законодавством. Ділова репутація таких працівників повинна відповідати, зокрема, таким вимогам, як відсутність непогашеної або не знятої в установленому законодавством порядку судимості за вчинення умисного злочину, а також відсутність вироку суду, за яким працівника засуджено до позбавлення права обіймати певні посади та займатися певною діяльністю.

Зокрема, службовці Національного банку, які $є$ державними службовцями, і тому на них поширюються вимоги законодавства про державну службу, а також Правила внутрішнього трудового розпорядку та посадові інструкції [14], повинні мати такі спеціальні вимоги щодо їх правосуб' єктності згідно із нормами Закону України «Про державну службу» від 10.12.2015 № 889-VIII [15]: повноліття та граничний вік 65 років; громадянство України; вільне володіння державною мовою; відповідний ступінь вищої освіти; дієздатність; відсутність непогашеної чи незнятої судимості; відсутність стягнень за корупційні правопорушення; професійна компетентність та багато інших умов).

Окремі вимоги щодо правосуб’єктності висунуто до інших категорій працівників фінансових установ, наприклад, до їхніх керівників та головних бухгалтерів (для цього було прийнято спеціальний нормативно-правовий акт - Професійні вимоги до керівників та головних бухгалтерів фінансових установ [16]). Керівники та головні бухгалтери фінансових установ перш ніж приступити до виконання своїх безпосередніх трудових обов'язків, зобов'язані пройти підвищення кваліфікації та скласти екзамен на відповідність знань професійним вимогам за типовою програмою підвищення кваліфікації керівників, головних бухгалтерів, складеною за напрямом діяльності фінансової установи та затвердженою Національною комісією з регулювання ринків фінансових послуг України. Окрім того, у Професійних вимогах до керівників та головних бухгалтерів фінансових установ [16] визначено, що керівник та головний бухгалтер, аби бути призначеними на свою посаду протягом останніх п'яти років, що передують призначенню, не повинні бути керівником, фінансовим директором або головним бухгалтером фінансової установи, визнаної банкрутом, підданої процедурі примусової ліквідації або до якої було застосовано захід впливу відповідним органом, який здійснює регулювання ринків фінансових послуг, у вигляді відсторонення керівництва від управління фінансовою установою та призначення тимчасової адміністрації.

Отже, правосуб'єктність як умова виникнення трудових правовідносин з працівниками фінансових установ включає такі ознаки:

- по-перше, особа, яка претендує на заняття посади у фінансовій установі, має володіти загальною трудовою правосуб' єктністю, тобто відповідати законодавчим вимогам щодо віку та стану здоров'я;

- по-друге, особа, яка претендує на заняття посади у фінансовій установі, має володіти спеціальною трудовою правосуб'єктністю, а також достатніми фізичними й розумовими здіб- 
ностями для зайняття відповідної посади, а також підвищеними професійними якостями, необхідними для виконання трудових обов'язків, передбачених відповідною посадою;

- по-третє, для різних посад у фінансовій установі ставляться різні вимоги щодо спеціальної трудової правосуб'єктності, а тому правосуб'єктність як умову виникнення трудових правовідносин з працівниками фінансових установ варто розглядати індивідуально у кожному конкретному випадку.

Наступною умовою виникнення трудових правовідносин 3 працівниками фінансових установ $є$ наявність правової норми, з моменту застосування норм якої правовідносини виникають і стають правовими. Як нами відзначалось раніше, норма права $\epsilon$ важливою умовою виникнення трудових правовідносин з працівниками фінансових установ, адже саме у ній знаходить своє визначення юридичний факт, який має юридичним наслідком виникнення трудових правовідносин із працівниками фінансових установ.

Насамперед серед таких нормативно-правових актів виділимо Кодекс законів про працю України [1], який вже згадувався нами та який визначає для працівників фінансових установ умови та гарантії прийняття на роботу. Але в той самий час варто враховувати те, що даним нормативно-правовим актом встановлюються загальні положення щодо регулювання трудових правовідносин, які не враховують специфіку функціонування банків, кредитних спілок, ломбардів, лізингових компаній, довірчих товариств, страхових компаній, установ накопичувального пенсійного забезпечення, інвестиційних фондів і компаній та інші юридичні особи, винятковим видом діяльності яких є надання фінансових послуг чи інших послуг (операцій), пов'язаних з наданням фінансових послуг. Зокрема, на службовців Національного банку поширюються вимоги законодавства про державну службу, тому, відповідно, на їх прийняття має вплив Закон України «Про державну службу» від 10.12.2015 № 889-VIII [15], а також Правила внутрішнього трудового розпорядку для працівників Національного банку України [14], які визначають загальні положення, порядок прийняття та звільнення службовців та іншого персоналу. Серед інших нормативно-правових актів, які тією чи іншою мірою впливають на виникнення трудових правовідносин 3 працівниками фінансових установ, варто відзначити Закони України «Про фінансові послуги та державне регулювання ринків фінансових послуг» від 12.07.2001 № 2664-III [2] та «Про банки та банківську діяльність» від 07.12.2000 № 2121-III [3], Професійні вимоги до керівників та головних бухгалтерів фінансових установ [16] та ряд інших нормативно-правових актів. Без норм зазначених нормативно-правових актів виникнення трудових правовідносин з працівниками фінансових установ $\epsilon$ неможливим.

Таким чином, норма права як умова виникнення трудових правовідносин з працівниками фінансових установ включає таке:

- по-перше, закріплення загальних умов виникнення трудових правовідносин з працівниками фінансових установ, серед яких передусім варто виділити унормування процесу укладення трудового договору;

- по-друге, юридичні факти, які зумовлюють виникнення будь-яких інших (суміжних) відносин між роботодавцями та працівниками фінансових установ, також знаходять своє закріплення у нормах чинного законодавства.

Останньою умовою виникнення трудових правовідносин 3 працівниками фінансових установ $є$ наявність юридичного факту, з яким чинне законодавство пов'язує виникнення правових наслідків і який $є$ юридичною підставою для виникнення правовідносин. У цьому контексті таким юридичним фактом $є$ укладення трудового договору. Як нами вже неодноразово відзначалось у цій роботі, укладення трудового договору здійснюється згідно зі статтею 21 Кодексу законів про працю України [1], зокрема визначено, що трудовим договором є угода між працівником і власником підприємства, установи, організації або уповноваженим ним органом чи фізичною особою, за якою працівник зобов'язується виконувати роботу, визначену цією угодою, з підляганням внутрішньому трудовому розпорядкові, а власник підприємства, установи, організації або уповноважений ним орган чи фізична особа зобов'язується виплачувати працівникові заробітну плату і забезпечувати умови праці, необхідні для виконання роботи, передбачені законодавством про працю, колективним договором і угодою сторін. Укладення такого договору і $€$ юридичним фактом, який є умовою виникнення трудових правовідносин з працівниками фінансових установ.

Висновки. Загалом, підсумовуючи специфіку виникнення трудових правовідносин з працівниками фінансових установ, варто відзначити наступне:

1) для виникнення трудових правовідносин з працівниками фінансових установ, особа, яка претендує на заняття вакантної посади в таких установах, має бути правосуб'єктною, тобто відповідати вимогам щодо віку, стану здоров’я, досвіду та рівня професійної компетенції; 
2) для виникнення трудових правовідносин з працівниками фінансових установ необхідна наявність правових норм, які урегульовують цей процес;

3) для виникнення трудових правовідносин з працівниками фінансових установ необхідна наявність юридичних фактів, закріплених у правових нормах, серед яких нами відзначено передусім укладення трудового договору.

\section{Список використаних джерел:}

1. Кодекс законів про працю України: Закон України від 10.12.1971 № 322-VIII. Вiдомості Верховної Ради УРСР від 17.12.1971. Додаток до N 50

2. Про фінансові послуги та державне регулювання ринків фінансових послуг: Закон України від 12.07.2001 № 2664-III. Відомості Верховної Ради України. 2002. № 1. Ст. 1.

3. Про банки і банківську діяльність: Закон України від 07.12.2000 № 2121-III. Відомості Верховної Ради України (ВВР). 2001. № 5-6. Ст. 30.

4. Загальна теорія держави і права: [Підручник для студентів юридичних вищих навчальних закладів] М.В. Цвік, О.В. Петришин, Л.В. Авраменко та ін.; За ред. д-ра юрид. наук, проф., акад. АПрН України М.В. Цвіка, д-ра юрид. наук, проф., акад. АПрН України О.В. Петришина. Харків : Право, 2009. 584 с.

5. Теорія держави та права : навч. посіб. [Є.В. Білозьоров, В.П. Власенко, О.Б. Горова, А.М. Завальний, Н.В. Заяць та ін.] ; за заг. ред. С.Д. Гусарєва, О.Д. Тихомирова. Київ : НАВС, Освіта України, 2017. 320 с.

6. Волинка К.Г. Теорія держави і права: Навч. посіб. Київ : МАУП, 2003. 240 с.

7. Зайчук О.В., Журавський В.С., Копиленко О.Л. та ін. Теорія держави і права. Академічний курс : [підручник] [О.В. Зайчук, В.С. Журавський, О.Л. Копиленко та ін.] ; за ред. О.В. Зайчука, Н.М. Оніщенко. Київ : Юрінком Інтер, 2006. 688 с.

8. Великий тлумачний словник сучасної української мови [гол. ред. В.Т. Бусел, редактори-лексикографи: В.Т. Бусел, М.Д. Василега-Дерибас, О.В. Дмитрієв, Г.В. Латник, Г.В. Степенко]. Київ : Ірпінь : Перун, 2005. 1728 с.

9. Положення про навчання, перепідготовку, підвищення кваліфікації та складання екзаменів особами, які провадять діяльність на ринках фінансових послуг: Розпорядження Держфінпослуг від 25.12.2003 № 183. Офічійний вісник Украйни офіційне видання від 20.02.2004. № 5 . Стор. 93. Стаття 260. Код акту 27604/2004.

10. Солодовник Л.В. Юридичні факти у трудовому праві України : дис. ... к. ю. н. : спец. 12.00.05 Х., 2004. $199 \mathrm{c}$.

11. Дмитренко Ю.П. Трудове право України : підручник. Київ : Юрінком Інтер, 2009. 624 с.

12. Сімутіна Я. В. Юридичні факти і динаміка трудових правовідносин. Юридичний вісник. Повітряне і космічне право. 2015. № 3. С. 109-113.

13. Основи законодавства України про охорону здоров'я: Закон України від 19.11.1992 № 2801-XII. Відомості Верховної Ради України. 1993. № 4. Ст. 19.

14. Правила внутрішнього трудового розпорядку для праці.вників Національного банку України Електронний ресурс. URL: http: bank.gov.ua/control/uk/publish/article?art_id=86889 (дата звернення 20.01.2020 року).

15. Про державну службу: Закон України від 10.12.2015 № 889-VIII. Відомості Верховної Ради. 2016. № 4. Ст. 43.

16. Про затвердження Професійних вимог до керівників та головних бухгалтерів фінансових установ: Розпорядження Державної комісії з регулювання ринків фінансових послуг України від 13.07.2004 № 1590. Офіціийний вісник Украӥни. 2004 р. № 31. Стор. 231. 